\title{
The first record of Notocyphus tyrannicus Smith, (Hymenoptera: Pompilidae) as parasitoid of Acanthoscurria Ausserer, 1871 (Teraphosidae: Teraphosinae)
}

\author{
A. L. Martins ${ }^{a *}$, J. E. Gallão $o^{b, c}$, M. E. Bichuette and E. F. Santos $^{d}$ \\ aLaboratório de Biologia Comparada de Hymenoptera, Programa de Pós-graduação em Entomologia, \\ Universidade Federal do Paraná - UFPR, CP 19020, CEP 81531-980, Curitiba, PR, Brazil \\ bPrograma de Pós-graduação em Biologia Comparada, Faculdade de Filosofia Ciências e Letras de \\ Ribeirão Preto - FFCLRP, Universidade de São Paulo - USP, Av. Bandeirantes, 3900, \\ Monte Alegre, CEP 14040-901, Ribeirão Preto, SP, Brazil \\ 'Laboratório de Estudos Subterrâneos, Departamento de Ecologia e Biologia Evolutiva, Universidade Federal de \\ São Carlos - UFSCar, Rodovia Washington Luiz, Km 235, CEP 13565-905, São Carlos, SP, Brazil \\ dDepartamento de Zoologia e Botânica, Instituto de Biociências, Letras e Ciências Exatas, Universidade Estadual \\ Paulista "Júlio de Mesquita Filho" - UNESP, Rua Cristóvão Colombo, 2265, \\ Jardim Nazareth, CEP 15054-000, São José do Rio Preto, SP, Brazil \\ *e-mail: andrelmartinsbiol@hotmail.com
}

Received: May 7, 2015 - Accepted: September 21, 2015 - Distributed: August 31, 2016 (With 1 figure)

Notocyphus Smith, 1855 is a diverse genus of Pompilidae represented by around 49 species and subspecies in the New World, and like most other pompilids, species of this genus are parasitoid of spiders (Wasbauer, 1995). Biological studies on Notocyphus have recorded species of Theraphosidae as its hosts (Williams, 1928; Lourenço, 1979; Minch, 1979; Simons, 1989; Sofia et al., 2011). Theraphosidae is one of 15 families of Mygalomorphae, including around 975 species in the world, and 179 in Brazil (Platnick, 2015). Herein, a new host of N. tyrannicus Smith, 1855 is presented, aiming to contribute to the biological knowledge of this parasitoid.

A juvenile spider of the genus cf. Acanthoscurria was collected in the wild, in Abaíra municipality, State of

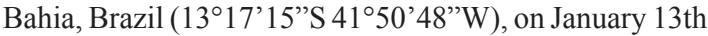
of 2014, and it was carried to the Subterranean Studies Laboratory, Department of Ecology and Evolutionary Biology at UFSCAR. The spider was kept alive with food and water at $23^{\circ} \mathrm{C}$. Twelve days after the specimen was captured a larva was observed stuck on spider's abdomen (Figure 1). The larva ate the spider ending it on January 31 st of 2014, when it entered the pupal stage, which lasted 46 days. A female of $N$. tyrannicus emerged on March 18 th of 2014

Williams (1928) recorded a female of $N$. tyrannicus hunting an arboreal theraphosid spider, probably of the genus Tapinauchenius Ausserer, 1871. Species of Acanthoscurria are nocturnal and live in tubular burrows under rocks, fallen trunks or in ravines close to the ground level, and sometimes, mainly in the reproductive season, they can be found during the day wandering outside their burrows (Gonzalez-Filho et al., 2012; Paula et al., 2014).

Basedonthe Williams' (1928) study, Evans (1953) classified species Notocyphus with the ethological sequence: Venari, Pungere, Ovum, Claudere (VPOC = hunting, paralysis, oviposition and nestclosing). However, no study has recorded species of Notocyphus closing its host in nest, indicating that species of this genus present the

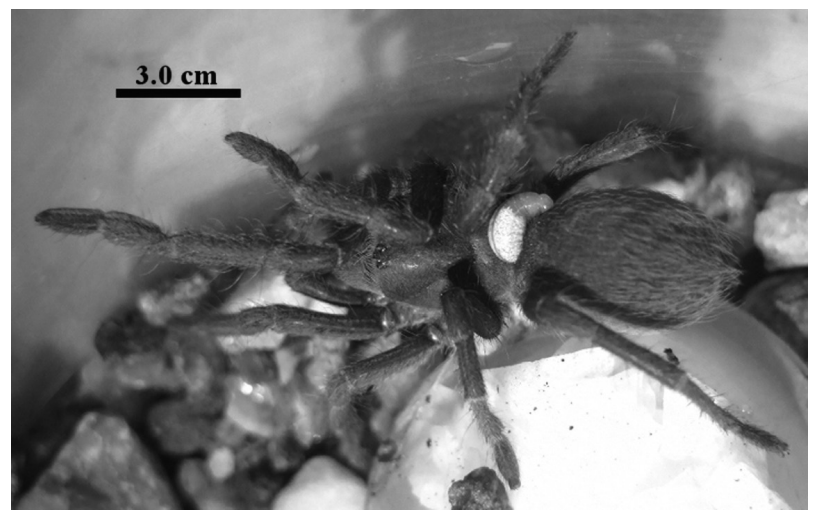

Figure 1. Specimen of an undetermined species of Acanthoscurria Ausserer, 1871 (Teraphosidae: Teraphosinae) with a larva of Notocyphulus tyrannicus Smith, 1855 (Hymenoptera: Pompilidae) stuck on the spider's abdomen. 
ethological sequence: hunting, paralysis and oviposition (VPO = Venari, Pungere, Ovum).

In conclusion this study expanded the knowledge on the host of Notocyphus and the parasitoids of species of the genus cf. Acanthoscurria. In addition, it shows that the biological knowledge on Notocyphus is still incomplete and more detailed studies could provide a better understanding on the natural history of this genus and its hosts.

\section{Acknowledgements}

We are very grateful to Coordination for the Improvement of Higher Education Personnel (CAPES) for the doctoral fellowship provided to A. L. Martins (CAPES Proc.:1399791); to National Counsel of Technological and Scientific Development of Brazil (CNPq) for the postdoctoral fellowships provided to E. F. dos Santos (CNPq - Proc.: 211689/2013-0) and for doctoral fellowship to J. E. Gallão (CNPq - Proc.: 142276/2013-8). We also thank Fapesp for the grant provided to M. E. Bichuette (Fapesp - Proc.: 2010/08459-4) and ICMBIO for the collection permit.

\section{References}

EVANS, H.E., 1953. Comparative ethology and the systematics of spider wasps. Systematic Zoology, vol. 2, no. 4, pp. 155-172. http://dx.doi.org/10.2307/2411559.

GONZALEZ-FILHO, H.M.O., LUCAS, S.M., PAULA, F.S., INDICATTI, R.P. and BRESCOVIT, A.D., 2012. On the Taxonomy of Acanthoscurria Ausserer from Southeastern Brazil with Data on the Natural History of A. gomesiana Mello-leitão (Araneae, Mygalomorphae, Theraphosidae). International Journal of Zoology, vol. 2012, pp. 1-11. http://dx.doi.org/10.1155/2012/721793.

LOURENÇO, W.R., 1979. Un Nouveau cas de parasitisme de Notocyphus tyrannicus Smith, sur une Mygale: Pamphobeteus sp. Revista Nordestina Biologia, vol. 2, no. 1, pp. 94-104.

MINCH, E.W., 1979. Notocyphus dorsalis arizonicus Townes (Hymenoptera: Pompilidae), a new host record of theraphosid spiders. The Wasmann Journal of Biology, vol. 37, no. 1-2, pp. 24-26.

PAULA, F.S., GABRIEL, R., INDICATTI, R.P., BRESCOVIT, A.D. and LUCAS, S.M., 2014. On the Brazilian Amazonian species of Acanthoscurria (Araneae: Theraphosidae). Zoologia, vol. 31, no. 1, pp. 63-80. http://dx.doi.org/10.1590/S198446702014000100008

PLATNICK, N.I., 2015 [viewed 23 January 2015]. World Spider Catalog. Version 16. Natural History Museum Bern [online]. Available from: http://wsc.nmbe.ch

SIMONS, L.H., 1989. A second record of Tarantula Parasitism by Notocyphus dorsalis arizonicus Townes (Hymenoptera: Pompilidae). The Pan-Pacific Entomologist, vol. 65, no. 1, pp. 34-37.

SOFIA, C., GABRIEL, P., JORGE, B. and NELSON, F., 2011. Datos preliminares acerca de Interacciones entre dos Avispas Pompílidas y Tarántulas em el Sur de Buenos Aires, Argentina. BioScriba, vol. 4, no. 1, pp. 13-20.

WASBAUER, M.S., 1995. Pompilidae. In: P.E. HANSON and I.D. GAULD, eds. The Hymenoptera of Costa Rica. Oxford: Oxford University Press, pp. 522-539.

WILLIAMS, F.X., 1928. Studies in tropical wasps their hosts and associates. Bulletin of the Experiment Station of the Hawaiian Sugar Planters'Association, vol. 19, pp. 1-179. 